\title{
AUXILIARY ISSUES OF BRANDING TOURISM DESTINATIONS: A CASE OF GAUTENG, SOUTH AFRICA
}

\author{
Michael KUSENI* \\ Tshwane University of Technology, Department of Tourism Management, Pretoria, Republic of South Africa, e-mail: michaelkuseni.mk@ gmail.com \\ Isa van AARDT \\ Tshwane University of Technology, Department of Tourism Management, Pretoria, Republic of South Africa, e-mail: VanAardtl@tut.ac.za
}

Liezel BOSHOFF

Tshwane University of Technology, Department of Tourism Management, Pretoria, Republic of South Africa, e-mail: BoshoffL@ @ut.ac.za

Citation: Kuseni, M., Aardt, I., \& Boshoff, L. (2021). AUXILIARY ISSUES OF BRANDING TOURISM DESTINATIONS: A CASE OF GAUTENG, SOUTH AFRICA. GeoJournal of Tourism and Geosites, 37(3), 823-831. https://doi.org/10.30892/gtg.37312-714

\begin{abstract}
Studies show very little evidence to support the concept that slogans and logos are not the only issues destination marketing companies should focus on in their branding efforts. Therefore, this study aims to figure out auxiliary critical issues of branding tourism destinations using Gauteng province as the study area. A mono quantitative survey method was used to validate and factor several issues which were identified in literature. A principal component factor analysis with Varimax rotation method was also conducted to identify the factors which were addressed by the destination managing authority. Five critical factors were identified, namely: destination image, market analysis, political stability, interior configuration and investment potentials. The results of this study therefore substantiated the supposition that branding is a useful marketing factor which succeeds if various aspects are taken into consideration. Establishing auxiliary critical issues is therefore vital for Tourism Destination Marketing Organisations (TDMO) as it can contribute knowledge towards the systematic and comprehensive brand implementation. Given that "product" includes a variety of things, among others provinces, towns, countries and organisations, application of the study results to a wide array of merchandises cannot be underplayed.
\end{abstract}

Key words: Tourism destination, destination branding, critical issues, stakeholders, Gauteng

\section{INTRODUCTION}

Tourism destinations are embroiled in a "spiral of place competition" (Lui, 2008; Metaxas, 2009; Turok, 2009), competing fiercely for tourists' money (Eghbali et al., 2015). As such, TDMOs are unable to differentiate their offerings with many achieving only "ephemeral difference (Pike, 2009: 857). Most of these destinations are depending on provision of high-quality service so as to differentiate themselves form the rest. However, it is becoming clear that differentiating strategies such as changing slogans and logo are becoming inadequate, if not ineffectual in the battle of customers (Mossberg and Kleppe, 2005). In such unassertive tourism environment, other aspects are becoming crucial intangible value creators for the branding process (Guzman and Montana, 2008). In this milieu, it is important to create strong brands by considering all aspects in the branding process so as to be able to differentiate tourism destinations (Vogt and Kaplanidou, 2010). Gauteng is a province which is regarded as one of the most sort after tourism destinations in the South African context (Gauteng Tourism Annual Report, 2013: 14). The province hosts multiflorous atrocity sites (Rogerson and Rogerson, 2014; Ivanovic, 2014) such as Soweto township, Johannesburg, Union Buildings, Voortrekker Monument, Constitutional Hill and Hector Peterson Memorial Museum which emerged as result of the apartheid regime.

The liberation of South Africans from the apartheid regime created a variety of heritage sites which have since been used as "cultural pots" for educating the current generation and future generation. As such, the province stands out to be "visitor magnet" attracting a competitive segment of the heritage market in the country. The province though hosts some of the 'hottest cultural pots', authentic cultural and heritage attributes, however, it is perceived as a crime manifested area. Such negative connotations have hindered the progression of tourism in the region.

In an attempt to erase the negative connotations, Gauteng Tourism Authority (GTA), which is the provincial tourism marketing organisation, have tried to brand the province several times to pursue people's mindset with slogans such as "it starts here", the "province of gold" and the "gateway to Southern Africa" (Brand, 2014: 164). In the process of branding, the TDMO formulates the identity of a place or region so that visitors build the desire of visiting it (Rijnks and Strijker, 2013; Ruzinskaite, 2015; de Rosa et al., 2017). In branding a destination, indeed slogans and logos have to be changed (Pike, 2009) but can be a superficial way of addressing destination rebranding issues.

This is partly because a slogan is just one element of place branding process (Goi and Goi, 2011: 448). Thus, concentrating on changing slogans, logos and brand names can be said to represent a situation of "changing bottles of the same wine". In fact, a destination may be facing a host of other challenges which need attention in a branding exercise

\footnotetext{
* Corresponding author
} 
(Hurombo, 2012; Malek and Costa, 2014). Therefore, this article attempts to establish other auxiliary critical issues of branding Gauteng as a tourist destination. Destination branding has become an emerging field of research in its embryonic stage (Leonardo and Rich, 2011) with relatively partial scholarly research (Saraniemi, 2011: 48; Kuseni, 2017: 16). In an attempt to bridge the gap, several implementation models have been proposed by scholars but lack practical application (Jesca, et al., 2014). Some studies by scholars such as Gartner (2007), Jeuring (2016), Bianchi and Stephenson (2013), Zenker and Rutter (2014) have tried to establish axillary critical issues but most tend to focus on single constructs. Considering these studies, literature is silent on coordinating the identified issues and measuring their relevance in an area (Kuseni, 2017). Consequently, there is an incomplete practical picture of the wholesome critical issues to destination like Gauteng province in South Africa. Against such background, the question is not whether destinations can be branded, but rather what needs to be considered to build desirable destination brands in this increasingly competitive market. With this in mind, the objectives of the study are;

- To establish critical issues of branding Gauteng province as tourism destination of choice.

- To identify critical issues addressed by GTA in their past branding exercise.

To answer the objectives, the study specifically focused on the main role players in the tourism industry within the province of Gauteng, which are the GTA employees, members affiliated to the Tourism Business Council of South Africa (TBCSA) and the tourists in Gauteng for they were felt to be appropriate holders of the subject understudy.

Table 1. Summary of models and noted issued (Source: Authors own compilation)

\begin{tabular}{|c|c|c|}
\hline AUTHORS & MODEL & ISSUS OUTLINED \\
\hline $\begin{array}{l}\text { Anholt } \\
(2016)\end{array}$ & Nation brand index & $\begin{array}{l}\text { - Tourism. } \\
\text { - Export. } \\
\text { - Governance. } \\
\text { - Investment and immigration. } \\
\text { - Culture and heritage. } \\
\text { - People. }\end{array}$ \\
\hline $\begin{array}{l}\text { Hankinson } \\
(2015)\end{array}$ & $\begin{array}{l}\text { Five guiding principles } \\
\text { of destination branding }\end{array}$ & $\begin{array}{l}\text { - Strong and visionary leadership. } \\
\text { - Brand-oriented organisational culture, } \\
\text { departmental coordination and process alignment. } \\
\text { - Consistent communication across a wide range of } \\
\text { stakeholders } \\
\text { Strong and compatible partnerships. } \\
\end{array}$ \\
\hline Haigh (2013) & Place branding toolkit & $\begin{array}{l}\text { - Logo and slogan. } \\
\text { - Associated visual image. } \\
\text { - Market research. } \\
\text { - Internal communication. } \\
\text { - External public relations. } \\
\text { - Advertising. }\end{array}$ \\
\hline $\begin{array}{l}\text { Rainisto } \\
\text { (2011) }\end{array}$ & $\begin{array}{l}\text { Nine success factors of } \\
\text { destination branding }\end{array}$ & $\begin{array}{l}\text { - Planning group. } \\
\text { - Visionary and strategic. } \\
\text { - Place identity and image. } \\
\text { - Public-private partnership. } \\
\text { - Leadership. } \\
\text { - Politics } \\
\text { - Global marketplace. } \\
\text { - Local development. } \\
\text { - Coincidences. }\end{array}$ \\
\hline Gartner (2011) & Political ideology model & - Political ideology. \\
\hline $\begin{array}{l}\text { Morgan, } \\
\text { Pritchard and } \\
\text { Pride (2009) }\end{array}$ & Five phases of branding & $\begin{array}{l}\text { - Market investigation, analysis and strategic } \\
\text { recommendation. } \\
\text { - Brand identity development. } \\
\text { - Brand launch, introduction and Communication of the } \\
\text { vision. } \\
\text { - Brand implementation. } \\
\text { - Monitoring, evaluation and review. }\end{array}$ \\
\hline $\begin{array}{l}\text { Balakrishnan } \\
\text { (2008) }\end{array}$ & Destination brand model & $\begin{array}{l}\text { - Vision. } \\
\text { - Stakeholders. } \\
\text { - Product portfolio. } \\
\text { - Target customer. } \\
\text { - Image differentiation. } \\
\text { - Communication. } \\
\end{array}$ \\
\hline $\begin{array}{l}\text { Konecnik and } \\
\text { Go }(2008)\end{array}$ & $\begin{array}{l}\text { Strategic brand analysis } \\
\text { model }\end{array}$ & $\begin{array}{l}\text { - Tourist analysis. } \\
\text { - Competitor analysis. } \\
\text { - Self-analysis. }\end{array}$ \\
\hline
\end{tabular}

\section{THEORECTICAL} FRAMEWORK

The Destination Branding process

Destination branding is the practice of applying branding strategy and other marketing techniques to the economic, political and cultural development of cities, regions, and countries (Ashworth and Kavaratzis, 2009). It is a process which informs, positions and differentiate a place from another (Singh, 2010). Destination branding communicates and assures a memorable experience tourists (Kemp et al., 2011: 122). Destination branding has become a crucial strategy for tourist destination marketers because a brand can identify and differentiate the destination through a positive image that holds tourists to the destination emotionally (Gnoth, 2007). Hankinson (2015) suggests a conceptual framework which underlines the leading role played by the TDMOs. The process starts with the TDMO establishing a clear vision and a strategy for brand building. This enables internal brand identity. Then brand is rolled out to build external brand identity (Baker, 2012). Afterwards, the brand is effectively communicated to multiple stakeholders through consistent brand communication

(Kavaratzis, 2009: 32; Cvijic and Guzijan, 2013: 23). Balakrishnan (2008) is of the opinion that destination branding begins with building a vision considered by all internal and external stakeholders. The vision incorporates natural assets, history, culture, infrastructure and/or facilities (product portfolio). The image is built to encompass the product portfolio to 
differentiate the destination. Local people such as residents disseminate positive world-of mouth which enhances the brand image to prospective customers (Eshuis et al., 2014; Rehmet and Dannie, 2013; Braun et al., 2013).

\section{Auxiliary critical issues in destination branding}

According to Pike (2009), brand positioning elements such as the names, symbols and slogans are used by the marketer to cut through the noise of competing and substitute products to stimulate an induced destination image that matches the brand identity. Destination image has an important role about destination selection of tourists (Korkmaz et al., 2014: 7). Bearing this in mind, TDMOs have created logos and slogans for their destinations to differentiate and promote themselves from others (Lee et al., 2011). However, can branding be only a product of changing logos and slogans? With massive competition in the service industry, focusing on changing logos and slogans can be a superficial way of addressing branding challenges (Hurombo, 2012). According to Kuseni (2017), this actuates the need to establish auxiliary critical issues of branding destinations (such as Gauteng province). If stakeholders accept the auxiliary critical issues of branding destination, they would be aware of their implications in branding and can implement sustainable destination brands (Hurombo, 2012; Jesca et al., 2014; Kuseni, 2017; Malek and Costa, 2014). Pike (2009) states that a slogan can indeed be changed but a slogan is just one element of place branding while Goi and Goi (2011: 448) assert that branding is not just about simply changing names. In view of the above statement, different scholars proposed models in relation to branding with different and similar issues. Table 1 represents the different and similar issues in this regard.

Table 2. Destination branding issues and the proposed critical issues (Source: Authors own compilation)

\begin{tabular}{|c|c|c|}
\hline Extracts from the models & Destination branding components & Proposed critical branding issues \\
\hline Self-analysis & \multirow{3}{*}{ To identify its true position in the market } & \multirow{3}{*}{ Self-analysis } \\
\hline Market research & & \\
\hline Market investigation & & \\
\hline Market analysis & To improve destination competitiveness & Competitor analysis \\
\hline Tourist analysis & \multirow{2}{*}{ To understand the needs of target customers } & \multirow{2}{*}{ Target customers } \\
\hline Target customers & & \\
\hline Strategic analysis & \multirow{2}{*}{ To develop a clear and shared vision for the branding process } & \multirow[b]{2}{*}{ Shared Vision } \\
\hline Vision & & \\
\hline Culture or heritage & \multirow{2}{*}{ To involve locals in developing and delivering the brand } & \multirow{2}{*}{ National culture } \\
\hline Organisation culture & & \\
\hline Public-private partnership & \multirow{2}{*}{ To balanced participation from all stakeholders } & \multirow{2}{*}{ Strong compatible partnerships } \\
\hline Compatible partnership & & \\
\hline Coincidences & \multirow{3}{*}{ To provide tourist needs within the destination. } & \multirow{3}{*}{ Product portfolio } \\
\hline Tourism & & \\
\hline Portfolio of product & & \\
\hline Stakeholders & \multirow{2}{*}{ To effectively manage stakeholders in branding } & \multirow{2}{*}{ Stakeholder management } \\
\hline Compatible partnership & & \\
\hline Strong and visionary leadership & \multirow{3}{*}{$\begin{array}{l}\text { To lead stakeholders so as to attain the vision of the } \\
\text { destination branding process }\end{array}$} & \multirow{3}{*}{ Strong and visionary leadership } \\
\hline Vision and strategic analysis & & \\
\hline Vision & & \\
\hline Image differentiation & \multirow{2}{*}{$\begin{array}{l}\text { To provide the link between the brand identity aspired by } \\
\text { TDMO and the actual brand image held in the market }\end{array}$} & \multirow{2}{*}{ Logo and slogan } \\
\hline Place identity and image & & \\
\hline Brand-oriented organisational culture & \multirow{2}{*}{$\begin{array}{l}\text { To build and extend the brand from the TDMOs to partner } \\
\text { organisations }\end{array}$} & \multirow{2}{*}{ Organisational culture } \\
\hline Culture or heritage & & \\
\hline Political ideology & To improve relations between destination and country & Political ideology \\
\hline Political unity & To promote unified decision- making. & Political unity \\
\hline Method used to govern & \multirow{2}{*}{$\begin{array}{l}\text { To promote fairness and trustworthiness in governing a } \\
\text { destination }\end{array}$} & \multirow{2}{*}{ Governance } \\
\hline Governance & & \\
\hline Place identity & \multirow{2}{*}{$\begin{array}{l}\text { To promote unique destination experience through } \\
\text { exporting home grown brands }\end{array}$} & \multirow{2}{*}{ Uniqueness of province } \\
\hline Product portfolio & & \\
\hline Place image & \multirow{2}{*}{ To create a positive destination image and positive publicity } & \multirow{2}{*}{ Image of province } \\
\hline Image differentiation & & \\
\hline Investment/ immigration & \multirow{2}{*}{$\begin{array}{l}\text { To enhance the development and improvement of the } \\
\text { tourism facilities }\end{array}$} & \multirow{2}{*}{ Domestic and foreign investment } \\
\hline Local development & & \\
\hline People & To promote brand acceptance and sustainability by locals & People/Host community \\
\hline Communicating the vision & \multirow{2}{*}{$\begin{array}{l}\text { To promote integration of all stakeholders in brand } \\
\text { formulation }\end{array}$} & Consistent communication \\
\hline Internal communication & & \\
\hline
\end{tabular}

\section{Evaluation and assimilation of destination branding models}

The models reviewed on Table 1 differ in several aspects, as they pinpoint certain suppositions which need to be noted. Gartner (2011) emphasises political ideology as the main issue to be addressed in destination branding. The rest take a broader perspective. Konecnik and Go (2008), and Morgan et al. (2016) somewhat emphasise the importance of market research in destination branding (target customer, competitor and self-analysis) while the importance of a publicprivate partnership in the planning and implementation of destination branding is highlighted by Rainisto (2011), 
Hankinson (2006) and Balakrishnan (2008). The scholars also share sentiments on the element of vision as a critical issue in destination branding. Rainisto (2011) and Anholt (2016) add the importance of political unity and governance. The outlined guidelines, factors and stages in models on Table 1 pave way and necessitates development of suppositions. The article picked and coded the guideline, stages and factors and developed suppositions which were believed to be critical in branding a destination as illustrated in Table 2.

\section{Study supposition}

The literature reviewed proposed conceptual assumptions which if intricately addressed, Gauteng province will be effectively branded to become a destination of choice. These are, self-analysis, competitor analysis, target customers, stakeholder management, strong and visionary leadership, shared vision, people/ host community, organisation culture, slogan and logo, strong and compatible partnerships, consistent communication, political ideology, political unity, governance, uniqueness of destination, Image of the destination, foreign and domestic investment, national culture promoting immigration and emigration, iconic attractions, accommodation, accessibility of the destination and ancillary services. However, the suppositions are theoretical without practical validity.

\section{MATERIALS AND METHODS}

This study adopted an exploratory deductive longitudinal research design. The target population for the study consisted of three strata in Gauteng. The units of analysis were GTA employees, members affiliated to TBCSA and tourists who were visiting the province. A total of 320 respondents were targeted and the distribution is shown in Table 1.

Research tactic applied was basically mono quantitative survey research based on probability and non-probability sampling designs. Probability method of stratification was adopted on the TBCSA members. 15 strata according to operational category were extrapolated and proportionally sampled. The method is preferred justifiable as it allowed blending of randomisation and categorisation. 136 respondents were sampled in this category. Non-probability methods of convenient, purposive and judgmental techniques were used to sample the tourists in Gauteng with a total of 100 respondents participating in the study while a simple random method was used for GTA employees with all 56 employees participating. A closed-ended questionnaire was used as a measuring instrument. Prior arrangements were made with the responsible authorities so as to conduct the study. Data was analysed using Strata V13 statistical software. Data analysis method were based on descriptive and inferential testing.

Table 3. Distribution of targeted respondents according to stratum

\begin{tabular}{|l|c|}
\hline \multicolumn{1}{|c|}{ Clusters } & Distribution \\
\hline GTA employees & 70 \\
\hline TBCSA members & 150 \\
\hline Tourists in Gauteng & 100 \\
\hline Aggregate total & 320 \\
\hline
\end{tabular}

\section{RESULTS AND DISCUSSION}

\section{Respondent's profile}

Interpretation of data plays an important role in research as it is the process that brings meaning to the views of the respondents. The findings of this study were derived from 320 respondents from Gauteng province. The respondents were from three different clusters namely: Gauteng Tourism employees (70), members affiliated to Tourism Business Council of South Africa (150) and tourist in Gauteng (100). The response rate of the respondents varied with clusters as shown in Table 4.

The overall response rate was $91 \%$ which can be rated as more than good. Babbie and Mouton (2004) note that a response of $50 \%$ is adequate while one of $60 \%$ is good. However, the response rate by levels varied as some questionnaires were emailed to the GTA. Pilot and Beck (2008: 305) note that emailed questionnaire response rate is usually less than $50 \%$. TBCSA members' response rate (91\%) recorded the second highest of the three levels. The response rate for GTA employees recorded the lowest $(80 \%)$ while the tourist in Gauteng recorded the highest (100\%).

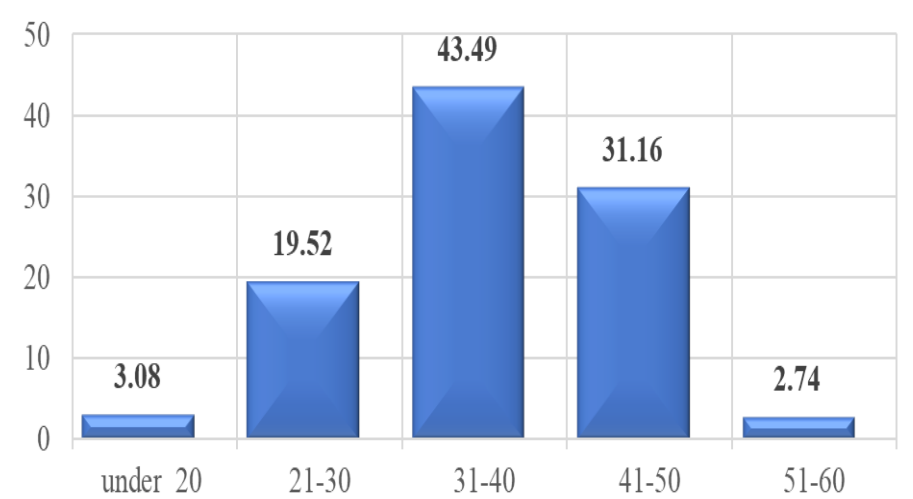

Figure 1. Age distribution of respondents $(\mathrm{N}=292)$

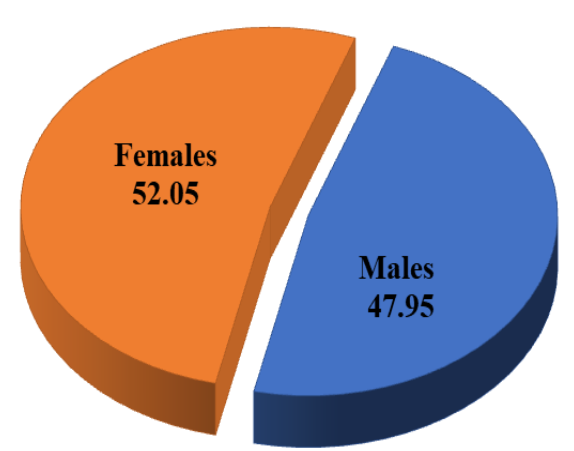

Figure 2. Distribution of respondents by gender $(\mathrm{N}=292)$ 


\section{Respondents demographic profile}

Respondents in the study were profiled based on their demographic characteristics with issues under consideration being age, gender, race, marital status and education levels. This was to ascertain if any of these characteristics can be considered in building a desirable destination brand. The socio-demographic and socio-economic characteristics of the respondents are presented in Figure1, 2, 3, 4, and 5.

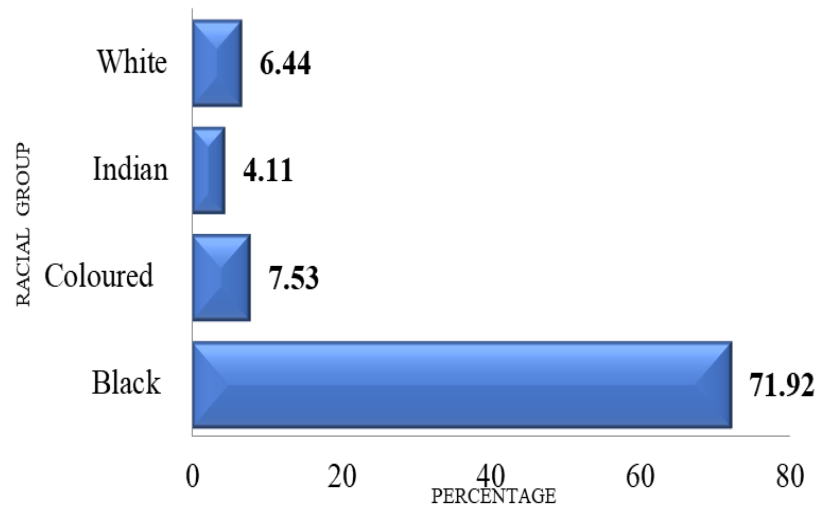

Figure 3. Distribution of respondents by race $(\mathrm{N}=292)$

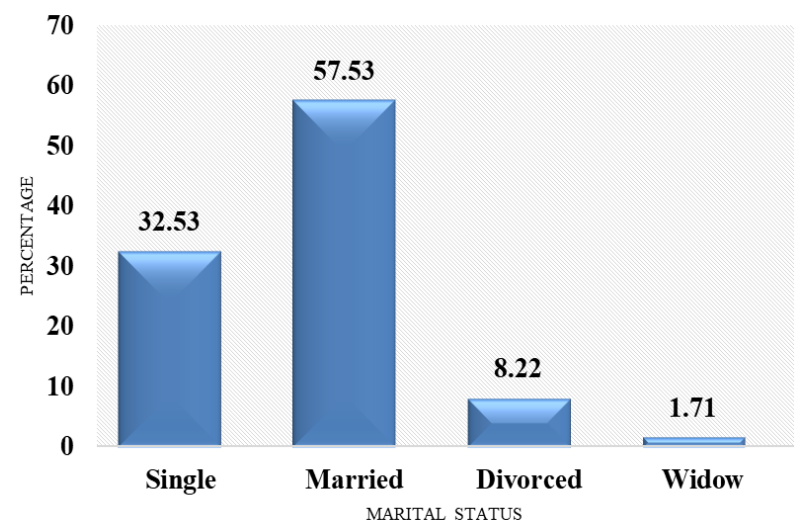

Figure 4. Distribution of respondents by marital status $(\mathrm{N}=292)$

The respondents were predominantly within two age groups, namely $31-40(43.49 \%)$ and $41-50(31.16 \%)$, with the least falling within the age group of 21-30 (2.74\%) years. More than four out of ten of the respondents fell in the age group of 31-40 years, while the two extreme age groups (under 20 years and 51-60 years) have less than 1 out of every 10. Gender composition was almost equal in distribution with males (52\%) and females (48\%).

There respondents were predominantly Africans. $71.95 \%$ were Africans, followed by Coloureds at $7.53 \%$, Whites at $6.44 \%$ and Indians at $4.11 \%$ of the respondents. The results showed that majority of respondents at $57.53 \%$ were married, $32.53 \%$ were single, followed by $8.22 \%$ who were divorced and $1.71 \%$ widowed.

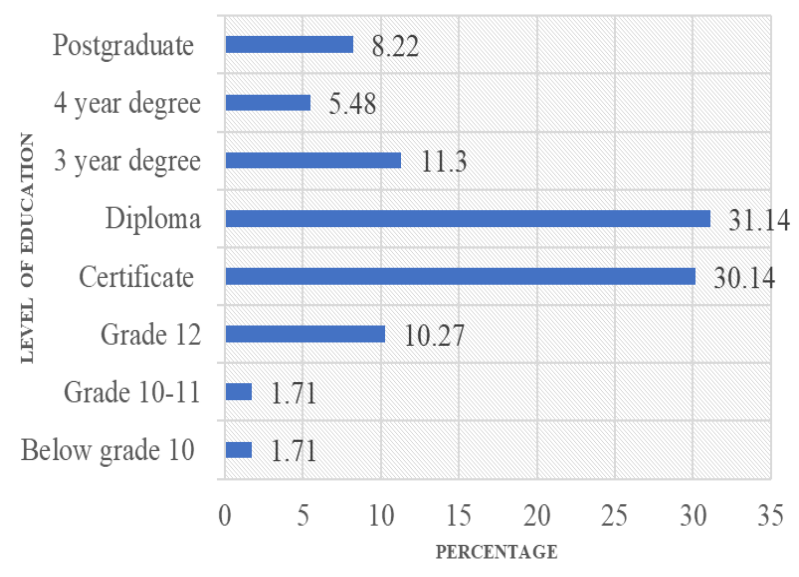

Figure 5. Distribution of respondents by level of education $(\mathrm{N}=292)$
Table 5. Distribution of respondents by brand awareness and source of brand awareness

\begin{tabular}{|c|c|c|c|c|c|c|c|c|c|}
\hline \multirow{3}{*}{\multicolumn{2}{|c|}{$\begin{array}{l}\text { CATEGORY OF } \\
\text { RESPONDENTS }\end{array}$}} & \multicolumn{2}{|c|}{ GTA } & \multicolumn{2}{|c|}{ TBCSA } & \multicolumn{2}{|c|}{$\begin{array}{c}\text { Tourists in } \\
\text { Gauteng }\end{array}$} & \multicolumn{2}{|c|}{ TOTAL } \\
\hline & & & & \multirow{2}{*}{\begin{tabular}{|c|}
$\mathbf{N}$ \\
136 \\
\end{tabular}} & \multirow{2}{*}{\begin{tabular}{|l|}
$\%$ \\
46 \\
\end{tabular}} & \multirow{2}{*}{$\frac{\mathrm{N}}{100}$} & \multirow{2}{*}{$\frac{\%}{34}$} & \multirow{2}{*}{\begin{tabular}{|c|}
$\mathbf{N}$ \\
292 \\
\end{tabular}} & \multirow{2}{*}{\begin{tabular}{|c|}
$\%$ \\
100 \\
\end{tabular}} \\
\hline & & & & & & & & & \\
\hline \multirow{2}{*}{$\begin{array}{c}\text { Brand } \\
\text { awareness }\end{array}$} & Aware of the brand & 56 & 100 & 122 & 90 & 87 & 85 & 265 & 90 \\
\hline & Not aware of the brand & 0 & 0 & 14 & 10 & 13 & 15 & 27 & 10 \\
\hline \multirow{7}{*}{$\begin{array}{c}\text { Source } \\
\text { of brand } \\
\text { awareness }\end{array}$} & Word-of-mouth & 2 & 4 & 57 & 47 & 37 & 42 & 96 & 36 \\
\hline & Public relation & 4 & 7 & 11 & 9 & 26 & 30 & 41 & 15 \\
\hline & Printed media & 8 & 14 & 27 & 22 & 17 & 20 & 52 & 20 \\
\hline & Website & 5 & 9 & 19 & 16 & 7 & 8 & 31 & 12 \\
\hline & Electronic medic & 12 & 21 & 5 & 4 & 0 & 0 & 17 & 6 \\
\hline & Travel expo & 3 & 5 & 3 & 2 & 0 & 0 & 6 & 9 \\
\hline & Roadshows & 22 & 40 & 0 & 0 & 0 & 0 & 23 & 9 \\
\hline
\end{tabular}

The majority of the respondents at $31.14 \%$ holds diploma qualifications and with certificate holders at $30.14 \%$. $11.30 \%$ of the respondents were qualified with a three-year degree, while $10.27 \%$ were matriculants. $8.22 \%$ of the respondents were post-graduates and $2.52 \%$ of respondents had either reached grade 11 or lower grade. The majority of the respondents were formally employed or self-employed $(90.75 \%)$.

\section{Responses for brand awareness and source of brand awareness}

Table 5 shows statistics of respondent's brand awareness and source of brand awareness over all three clusters which are the employees of both GTA and TBCSA, as well as tourists in the province. The results showed that majority (90\%) of the total respondents were aware of the GTA brand awareness programmes. All GTA employees (56) were aware of branding programmes (100\%). Of the 136 respondents from the TBCSA respondents, $90 \%$ were aware of the branding by GTA while out of the 100 respondents of tourists in Gauteng, 85\% were aware of the branding programmes. Considering the overall percentage of $90 \%$, it is clear that the respondents were aware of GTA branding hence the targeted population was conversant in the topic under study. On the source of brand awareness, from the 56 respondents from GTA, 40\% heard of the province's tourism brand through roadshows, $21 \%$ through electronic media and only $4 \%$ of the respondents heard through the word-of-mouth. From the TBCSA (136), 47\% of the respondents heard through the word-of-mouth, $22 \%$ from printed media and only $2 \%$ form roadshows. $42 \%$ of the 100 tourists visiting Gauteng heard branding through word-of-mouth, $30 \%$ from public relations and $20 \%$ from printed media. 


\section{Descriptive statistics of GTA branding efforts against other provinces in South Africa}

The descriptive statistics of GTA branding efforts against other provinces in South Africa were established based on a scale 1 (very poor) to 5 (very good). Table 6 shows the mean and standard deviations of Gauteng against other provinces.

The Mean Scores from the respondents indicated that the Western Cape (77.86\%) and Kwa-Zulu Natal Tourism Authorities $(70.86 \%)$ were better rebranding formulators than the GTA recording. North West and Northern Cape were poor brand formulators recording the highest percentages on the lower scales, $76.47 \%$ and $70.48 \%$ respectively.

\section{Descriptive statistics and Factor Analysis of critical issues in branding Gauteng province}

A survey of attitudes of GTA employees, TBCSA members and tourists to Gauteng about the importance of 22 elements on branding Gauteng province was conducted in 2016. The 22 constructs identified in the literature were tested on a five-point Likert Scale ranging from Not at all critical (1) to Very critical (5). The analysis of the results shows that all respondents felt that all elements were very critical scoring above 2.5. A similar trend was also revealed in the other constructs such as destination analysis, competitor analysis, target customer, stakeholder management, strong and visionary leadership, shared vision, host community slogan and logo, strong and compatible partnership, consistent communication, uniqueness of the destination, image of the destination national culture, attractions, accommodation, accessibility and ancillary services. On these variables, the high average scores were given by TBCSA members, followed by GTA employees and the tourists to Gauteng scoring least average. However, on organisational culture, political ideology, political unity and governance higher ratings were scored by the tourists to Gauteng followed by GTA employees while the members of TBCSA had the least average scores. The trend was opposite with regards to political issues where tourists were of the opinion that political issues affected branding exercise more. On the foreign and domestic investment element, GTA employees rated it higher (4.33), followed by TBCSA members (4.18) and tourists to Gauteng (3.98). While all respondents affirmed the critical issues identified on the micro-destination, variations were noted in how different strata rated the constructs. To reduce the multiplicity of the constructs established prior, an exploratory factor analysis was conducted on the 22 constructs.

Table 6. Comparisons of GTA rebranding efforts compared to other provinces in SA $(\mathrm{N}=292)$

\begin{tabular}{|c|c|c|}
\hline $\begin{array}{c}\text { Comparisons of GTA } \\
\text { rebranding efforts } \\
\text { compared to other } \\
\text { provinces }\end{array}$ & \multicolumn{2}{|c|}{$\begin{array}{c}\text { Number of } \\
\text { respondents }\end{array}$} \\
\cline { 2 - 3 } & $\begin{array}{c}\text { Mean } \\
\text { (mode })\end{array}$ & Std D \\
\hline Eastern Cape & $3.54(3)$ & 0.85 \\
\hline Free State & $3.51(3)$ & 0.77 \\
\hline Kwa-Zulu-Natal & $2.23(2)$ & 0.94 \\
\hline Limpopo & $3.66(4)$ & 0.93 \\
\hline Mpumalanga & $3.37(3)$ & 0.84 \\
\hline Northern Cape & $4.01(3)$ & 0.95 \\
\hline North West & $4.10(4)$ & 0.96 \\
\hline Western Cape & $2.06(2)$ & 1.06 \\
\hline
\end{tabular}

A principal component factoring analysis with Orthogonal Varimax rotation of 22 variables was performed. The results yielded a five-factor solution structure (factor loadings $\Rightarrow$ 0.40) with acceptable levels of reliability. The consortium includes destination image, interior configuration, destination market analysis, political stability in province and investment potentials. A Bartlett's test of specificity indicated that factors yielded $p$ values of $<0.001$, hence the correlation structure is valid for a factor analysis. Five factors extracted accounted for $63 \%$ of total variance. These are shown in Table 7 below.

The second primary objective of the study

was to establish if the GTA has addressed the identified critical issues identified. A survey was conducted with the same respondents and their attitudes were evaluated on Likert scale (1-5) strongly disagree (1) to strongly agree (5). Most of the elements scored overall mean score below 3.5 which is sufficient evidence that the respondents felt that 19 issues of the 22 critical issues identified in branding Gauteng have not been addressed. Some of the constructs are: stakeholder management (2.46), strong and visionary leadership (2.53), shared vision (2.37), host community (2.46), strong and compatible partnership (2.54) consistent communication (2.48), political ideology (3.22), uniqueness of the destination (2.96), image of the destination (2.54) and national culture (2.59). The constructs that the participants rated the highest, indicating that they have been addressed are: attractions (4.11), accommodation (4.24) and accessibility (4.16). A further analysis of the results also showed variation of scores among the three strata as shown on Table 8 . 
The results on Table 8 show variation among the three strata. On the first table labelled A, the TBCSA members rated the elements: destination analysis, customer analysis, target customer, organisational culture, slogan and logo and accommodation higher as not being addressed by GTA while those under B, the general public rated stakeholder management, host community, strong compatible partnership, consistent communication, uniqueness of the destination, image of the destination, foreign and domestic investment and ancillary services higher than the other constructs.

On table labelled C, GTA employees scored the variables strong and visionary leadership, and shared vision higher than the other strata. On table labelled D, the members of the TBCSA rated political ideology, political unity, governance, attractions, accommodation and accessibility as addressed with higher scores than GTA employees and tourists to Gauteng. The results therefore show that the three groups of respondents though agreed on the opinion of not satisfactory addressed, their opinions were slightly different based on the critical issues.

A factor analysis approach was used on the critical issues addressed for branding Gauteng province. A factor loading matrix using the rotation axis factoring extraction method was used for the analysis how distinct the factors were.

A factor analysis was conducted and four factors were established with a reliability co-efficiency of not less than 0.83. Rather than using the 22 variables, 4 factors namely: destination image, destination market analysis, destination configuration and politics in the province imaged. A Kaiser-Meyer-Olkin measure of sampling adequacy was also undertaken and the variables attained a statistic of 0.88 for identification of the critical issues which is above 0.8 indicating that sampling was adequate as shown on Table 9.

Table 8. Distribution of critical issues addressed ( $\mathrm{N}=292)$

\begin{tabular}{|c|c|c|c|c|c|c|}
\hline \multirow[t]{2}{*}{$\mathbf{A}$} & \multirow[t]{2}{*}{ Variables } & \multicolumn{3}{|c|}{$\begin{array}{l}\text { STRATA MEAN } \\
\text { SCORE }\end{array}$} & \multirow{2}{*}{$\begin{array}{c}\text { Overall } \\
\text { Mean } \\
\text { (Median) }\end{array}$} & \multirow{2}{*}{$\begin{array}{c}\text { Overall } \\
\text { Standard } \\
\text { Deviation }\end{array}$} \\
\hline & & GTA & TBCSA & GP & & \\
\hline 1 & Destination analysis & 3.11 & 3.37 & 3.14 & $3.24(3)$ & 0.75 \\
\hline 2 & Customer analysis & 3.16 & 3.26 & 3.17 & 3.21(3) & 0.78 \\
\hline 3 & Target customer & 2.95 & 3.10 & 3.10 & 3.07(3) & 0.84 \\
\hline 8 & Organisational culture & 3.12 & 3.25 & 3.22 & 3.22(3) & 0.81 \\
\hline 9 & Slogan and logo & 3.58 & 4.21 & 3.65 & $3.89(4)$ & 1.03 \\
\hline 20 & Accommodation & 4.35 & 4.40 & 3.96 & 4.24(4) & 0.83 \\
\hline \multicolumn{7}{|l|}{ B } \\
\hline 4 & Stakeholder managemen & 2.53 & 2.16 & 2.82 & $2.46(2)$ & 0.88 \\
\hline 7 & Host community & 2.54 & 2.11 & 2.90 & $2.46(2)$ & 0.96 \\
\hline 10 & $\begin{array}{|ll|}\begin{array}{l}\text { Strong } \\
\text { partnership }\end{array} & \text { compatible } \\
\end{array}$ & 2.72 & 2.27 & 2.81 & $2.54(2)$ & 0.80 \\
\hline 11 & $\begin{array}{l}\text { Consistent } \\
\text { communication }\end{array}$ & 2.56 & 2.23 & 2.78 & $2.48(2)$ & 0.88 \\
\hline 15 & $\begin{array}{l}\text { Uniqueness of the } \\
\text { destination }\end{array}$ & 3.02 & 2.78 & 3.16 & $2.96(3)$ & 0.93 \\
\hline 16 & $\begin{array}{l}\text { Image of the } \\
\text { destination }\end{array}$ & 2.68 & 2.15 & 3.00 & $2.54(2)$ & 0.98 \\
\hline 17 & $\begin{array}{l}\text { Foreign \& domestic } \\
\text { investment }\end{array}$ & 2.93 & 3.41 & 3.29 & $3.27(3)$ & 0.91 \\
\hline 22 & Ancillary services & 3.79 & 3.99 & 3.85 & $3.90(4)$ & 0.93 \\
\hline \multicolumn{7}{|l|}{$\mathbf{C}$} \\
\hline 5 & $\begin{array}{l}\text { Strong and visionary } \\
\text { leadership }\end{array}$ & 2.84 & 2.21 & 2.78 & $2.53(2)$ & 0.86 \\
\hline 6 & Shared vision & 2.74 & 1.99 & 2.64 & $2.37(2)$ & 0.89 \\
\hline \multicolumn{7}{|c|}{ 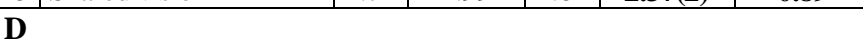 } \\
\hline 12 & Political ideology & 3.14 & 3.39 & 3.05 & 3.22(3) & 0.93 \\
\hline 13 & Political unity & 3.18 & 3.44 & 3.00 & 3.24(3) & 0.91 \\
\hline 14 & Governance & 3.11 & 3.32 & 2.99 & $3.16(3)$ & 0.92 \\
\hline 19 & Attractions & 4.00 & 4.27 & 3.95 & 4.11(4) & 0.88 \\
\hline 20 & Accommodation & 4.35 & 4.40 & 3.96 & 4.24(4) & 0.83 \\
\hline 21 & Accessibility & 4.14 & 4.24 & 4.07 & 4.16(4) & 0.86 \\
\hline
\end{tabular}

Table 9. Factor analysis: critical issues addressed when rebranding Gauteng

\begin{tabular}{|l|c|c|c|}
\hline FACTORS AND VARIABLES & $\begin{array}{c}\text { Factor } \\
\text { loading }\end{array}$ & $\begin{array}{c}\text { Mean } \\
\text { Value }\end{array}$ & $\begin{array}{c}\text { Reliability } \\
\text { Coefficient } \\
\text { (alpha) }\end{array}$ \\
\hline $\begin{array}{l}\text { Factor 1: Destination } \\
\text { management }\end{array}$ & & $\mathbf{. 3 4 9 3 8 9}$ & $\mathbf{0 . 8 7 0 5}$ \\
\hline Stakeholder management & 0.7288 & & \\
\hline Strong and visionary leadership & 0.6865 & & \\
\hline Shared vision & 0.7727 & & \\
\hline Host community & 0.6826 & & \\
\hline Strong and compatible partnership & 0.7031 & & \\
\hline Consistent communication & 0.7386 & & \\
\hline Uniqueness of the destination & 0.4218 & & \\
\hline Image of the destination & 0.7805 & & \\
\hline National culture & 0.5764 & & \\
\hline $\begin{array}{l}\text { Factor 2: Destination market } \\
\text { analysis }\end{array}$ & & $\mathbf{. 3 6 5 1 9 2}$ & $\mathbf{0 . 8 3 6 8}$ \\
\hline Destination analysis & 0.8101 & & \\
\hline Customer analysis & 0.8107 & & \\
\hline Target customer & 0.7274 & & \\
\hline Organisational culture & 0.5445 & & \\
\hline Slogan and logo & 0.6380 & & \\
\hline $\begin{array}{l}\text { Factor 3: Destination } \\
\text { configuration }\end{array}$ & & $\mathbf{. 4 0 2 7 1 0}$ & $\mathbf{0 . 8 4 2 6}$ \\
\hline Foreign and domestic investment & 0.4065 & & \\
\hline Attractions & 0.8075 & & \\
\hline Accommodation & 0.7698 & & \\
\hline Accessibility & 0.8373 & & \\
\hline Ancillary services & 0.8113 & & \\
\hline Factor 4: Politics in the province & & $\mathbf{. 5 8 2 0 8 5}$ & $\mathbf{0 . 8 6 8 9}$ \\
\hline Political ideology & 0.7995 & & \\
\hline Political unity & 0.8564 & & \\
\hline Governance & 0.7311 & & \\
\hline
\end{tabular}

\section{CONCLUSION}

The main purpose of study was to establish the critical issues in branding and finding out if the identified critical issues have been addressed by the TDMO. The study finds out that all the suppositions reviewed in literature are critical in branding the Gauteng province, with some fine variation being noted. Political ideology, political unity and governance were the least critical issues. The 22 critical issues identified were later factored to five critical issues namely: destination image, interior configuration, destination market analysis, political stability in province and investment potentials. In this respect, instead of management considering the 22 critical issues, it is therefore wise for them to consider the five factors.

On critical issues addressed, the study found out that most of the critical issues identified were not addressed save for accommodation, accessibility and attractions. Instead of management trying to master the 22 critical issues not addressed, it is ideal for them to consider the four factors namely: destination management, destination market analysis, 
destination configuration and politics in the province. Based on the findings and conclusions of this study, GTA should address destination image variables which are: slogan and logo, consistent communication, uniqueness of a destination, attractions, accommodation, accessibility and ancillary services. GTA should also address the interior configuration variables which are stakeholder management, strong and visionary leadership, shared vision and host community. Destination market analysis variables of destination analysis, customer analysis and target customer should also be considered. The problem of political instability should be addressed by political ideology, political unity and governance. The nature of the variables calls for addressing it at the highest political level of the province.

Concrete efforts should be made by the GTA to render better support services in the province so as to address investment potentials through provision of a good organisational culture, a foreign and domestic investment climate and a national culture. From the above recommendations, one can recommend that the GTA should think outside the box and include all of the identified critical issues in their branding exercise so that Gauteng becomes a destination of choice. The findings of the study are expected to assist practitioners in branding tourism destination and also increasing awareness of brand implementation most specifically to the TDMOs.

\section{Acknowledgement}

The authors hereby give credit Mr Madiseng Messiah Phori for reviewing the article. Credit is also given to Mr F. Ngqobe (GTA HEAD: Chief Executive Officer of Gauteng Tourism Authority) and P. B. Mathebula (Ekurhuleni Tourism Authority) for granting him permission to undertake the study. Further credit is given to M. Mashige (GTA Brand Marketing Manager) for helping with the distribution and collection of the survey questionnaires to and from the participants at GTA. The authors would like to thank the respondents who participated in the survey.

\section{REFERENCES}

Anholt, S. (2016). Place, identity, image reputation. Palgrave McMillan.

Ashworth, G.J., \& Kavaratzis, M. (2009). Beyond the logo: brand management for cities. Journal of Brand Management, 6(8), $520-531$. https://doi.org/10.1057/palgrave.bm.2550133

Babbie, E. \& Mouton, J. (2004). The practice of social research. Oxford University Press.

Baker, B. (2012). Destination branding for small cities: the essentials for success place branding. $2^{\text {nd }}$ ed. Portland, Oregon.

Bianchi, R.V., \& Stephenson, M.L. (2013). Deciphering tourism and citizenship in a global world. Tourism management, 39, 10-20. https://doi.org/10.1016/j.tourman.2013.03.006

Balakrishnan, M.S. (2008). Dubai - A star in the East: a case study in strategic destination brand. Journal of place management and development, 1(1), 1757-8335. https://doi.org/10.1108/17538330810865345

Brand, S.A. (2014). South Africa 20 years of success government and business. In: T.M. Ltd, South Africa 20 years of success Government and Business, (pp. 162-180), Cape Town: Topco, ISBN 978-0-61594-5.

Braun, E., Kavaratzis, M., \& Zenger, S. (2013). My city - my brand: the different roles of resident in place branding. Journal of place and development, 6(1), 18-28. https://doi.org/10.1108/17538331311306087

Cvijic, J., \& Guzijan, J. (2013). Cultural and historical heritage - an asset for city brands. Sputum international review, $30,23-27$. https://doi.org/10.2298/SPAT1330023C

De Rosa, A.S., E. Bocci, \& Dryjanska, L. (2017). Social representation of the European capitals and destination e-branding via multi-channel web communication. Journal of Destination Marketing \& Management, Advance online publication. https://doi.org/ 10.1016/j.jdmm.2017.05.004

Eghbali, N., Kharazmi, O.A., \& Rahnama, M.R. (2015). Assessing Effective Factors for the Formation of City Image in Mashhad from the view point of Tourists by Structural Equation Modeling. Science Journal, 36(3), 133-148. https://doi.org/10.50431.profdoc.um.ac.ir.articles.a

Eshuis, J. Klijn, E.H., \& Braun, E. (2014). Place marketing and participation: branding a strategy to address the emotional dimension of policy making? International review of administrative sciences, 80(10,151-171. https://doi.org/10.1177/0020852313513872

Field, A. (2009). Discovering statistics using SPSS. $3^{\text {rd }}$ ed. London, Sage Publications.

Gartner, D. (2011). Place branding: a dilemma between political ideology and economic pragmatism? Journal of place branding and public diplomacy, 3(1), 3-7. https://doi.org/10.1057/palgrave.pb.6000053

Goi, C., \& Goi, M. (2011). Unfolding and configuring two decades of research of publications on place marketing and place branding. Place branding and public diplomacy, 2(2), 91-106. https://doi.org/10.1057/PB.2011.7

Gnoth, J. (2007). The structure of destination brands: leveraging values. Tourism Analysis, 12(6), 345-358. https://doi.org/10.3727/ 108354207783227939

Guzman, F., \& Montana, J. (2008). Branding and design management: handbook on brand experience. UK: Edward Elgar publishing Ltd.

Haigh, G. (2013). From destination brand to location 1. Journal of Brand Management, 13(4-5), 276-283.

Hankinson, G. (2015). Rethinking the place branding constructs. Rethinking place branding, 13-31. https://doi.org/10.1007/978-3-319-12424-7

Hankinson, G. (2007). The management of destination brands: five guiding principles based on recent developments in corporate branding theory. Journal of brand management, 14(3), 240-254. https://doi.org/10.1057/palgrave.bm.255006

Hurombo, B. (2012). Critical issues in rebranding tourism destination: evidence from Zimbabwe tourism Authority. Masters' dissertation, University of Zimbabwe. Unpublished.

Hurombo, B., Kaseke, N., \& Muzondo, N. (2014). Critical issues in (re)branding: evidence from Zimbabwe's national tourism organisation. Business review, 2(2), 61-76.

Ivanovic, M. (2014). The Perceived Authenticity of Iconic Heritage Sites in Urban Tourism: the case of Constitutional Hill, Johannesburg, South Africa. Urban Forum, 25, 501-515. https://doi.org/10.1007/s12132-014-9241-5

Jesca, C., Kumbirai, M., \& Hurombo, B. (2014). Destination rebranding paradigm in Zimbabwe: a stakeholder approach. Journals of advanced research in management and social science, 3(1), 1-12. 
Jeuring, J.H.G. (2016). Discursive contradictions in regional tourism marketing strategies: the case of Fryslan, The Netherlands. Journal of destination marketing and management, 5(2), 65-75. https://doi.org/10.1016/j.jdmm.2015.06.002

Kavaratzis, M. (2009). Cities and their brands: lessons from corporate branding, Place Branding and Public Diplomacy, 5(1), $26-37$. https://doi.org/10.1057/pb.2008.3

Kemp, E., Williams, K.H., \& Bordelon, B.M. (2011). The impact of marketing on internal stakeholders in destination branding: The case of a musical city. Journal of Vacation Marketing, 18(2), 121-133. https://doi.org/10.1177/1356766712443469

Konecnik, M., \& Go, F. (2008). Tourism destination: Brand identity, the case of Slovenia. Journal of brand management, 15(3), 177189. https://doi.org/10.1057/palgrave.bm.2550114

Korkmaz, H., Mercan, O., \& Atay, L. (2014). The Role of Cittaslow in Destination branding: the case of Seferihisar. Current Issues of Tourism Research, 4(1), 5-10.

Kuseni, M. (2017). Critical issues in destination branding of Gauteng. Masters' dissertation; Tshwane University of Technology, South Africa, Unpublished.

Lee, J., Lee, C., \& Choi, Y. (2011). Examining the role of emotional and functional values in festival evaluation. Journal of Travel Research, 50(6), 685-696. https://doi.org/10.1177/0047287510385465

Leonardo, A.N.D., \& Rich, H. (2011). Affirmation, assimilation and anarchy: critical undercurrents in destination branding. International journal of culture, tourism and hospitality research, 5(3), 215-226. https://doi.org/10.1108/17506181111156916

Lui, T. (2008). City-branding without content: Hong Kong's aborted West Kowloon mega project 1998-2006. International development planning review, 30(3), 215-226. http://dx.doi.org/10.3828/idpr.30.3.2

Malek, A., \& Costa, C. (2014). Integrating communities into tourism planning through social innovation. Tourism planning and development, 12(3), 207-230. https://doi.org/10.1080/21568316.2014.951125

Metaxas, T. (2009). Place marketing, strategic planning and competitiveness: the case of Malta. European planning studies, 17(9), 13571378. https://doi.org/10.1080/09654310903053539

Morgan, N., Pritchard, A., \& Pride, R. (2009). Destination branding: creating unique destination proposition. Oxford, UK: Elsevier Ltd.

Mossberg, L., \& Kepple, I.A. (2005). Country and destination image- different or similar image concepts? The service industries journal, 25(4), 493-503. https://doi.org/10.1080/02642060500092147

Pike, S.D. (2009). Destination brand positions of competitive set near-home destinations. Journal of tourism management, 30(3), 857866. https://doi.org/10.1016/j.tourman.2008.12.007

Polit, D. \& Beck, C. (2008). Nursing research: generating and assessing evidence for nursing practice. 8th edition. Philadelphia: Lippincott Williams \& Wilkins.

Rainisto, S. (2011). Success factors of place branding. Regional magazine, 267(1), 20-22. https://doi.org/10.1080/13673882.20078628829

Rehmet, J., \& Dinnie, K. (2013). Citizen brand ambassadors; motivations and perceived effects. Journal of Destination Marketing AND Management, 2(1), 31-38. https://doi.org/10.1016/j.jdmm.2013.02.001

Rijnks, R.H., \& Strijker, D. (2013). Spatial image on the image and identity of a rural area. Journal of environmental psychology, 36, 103-111. https://doi.org/10.1016/j.jenvp.2013.07.008

Rogerson, C.M., \& Rogerson, J.M. (2014). Urban tourism destinations in South Africa: divergent trajectories, 2001-2012. Urban Izziv, 25, S189-S203. https://doi.org/10.5379/urbani-izziv-en-2014-25-supplement-014

Ruzinskaite, J. (2015). Place branding: the need for an evaluative framework. Thesis, University of Huddersfield (Salford).

Saraniemi,S. (2011). From destination image building to identity-based branding. International journal of culture, tourism and hospitality research, 5(3), 247-254. https://doi.org/10.1108/17506181111156943

Singh, K.A. (2010). Destination branding: an introduction. Punjagutta: The Icfai University. Ch. 2.

Turok, I. (2009). The distinctive city: pitfalls in the pursuit of differential advantage. Environmental and planning A, 41(1)13-30. https://doi.org/10.1068/a37379

Vogt, C., \& Kaplanidou, K. (2003). Destination branding: concepts and measuring in concepts and measurement: Travel Michigan and Michigan State University.

Zenker, S., \& Rutter, N. (2014). Is satisfaction the key? The role of citizen's satisfaction, place attachment and brand attitude on positive citizen's behavior. Cities, 38, 11-17. https://doi.org/10.1016/j.cities.2013.12.009

*** Gauteng Tourism Authority (GTA) Annual Report 2012-13.

*** Gauteng Tourism Authority (GTA) Annual Report 2013-14.

*** Gauteng Tourism Authority (GTA) Annual Report 2017-18.

Article history: Received: 27.04.2021 Revised: 26.07.2021 Accepted: 23.08.2021 Available online: 14.09.2021

